\title{
La influència del llenguatge de missatgeria instantània en l'alumnat de 6è de primària
}

\section{Robert Cid Górriza ${ }^{\text {a Núria Gil Duran }}{ }^{\mathrm{b}}$ i Míriam Segura Meix ${ }^{\mathrm{c}}$}

Rebut: 19/11/2015 Acceptat: 21/12/2015

\section{Resum}

La present investigació té la finalitat d'aportar nou coneixement a una de les problemàtiques que més ressò té en el món educatiu actual i en l'àmbit lingüístic: el llenguatge de missatgeria instantània. Aquesta va encaminada a conèixer l'estat actual de la qüestió i a identificar si l'alumnat de 6è de Primària d'un centre escolar de Tortosa presenta en la seva escriptura la influència d'aquest tipus de llenguatge. $A$ continuació, es pretén valorar aquesta influència i les seves característiques. Es realitzen diverses activitats d'expressió escrita a l'aula utilitzant diferents suports TIC i tradicionals i es procedeix a enquestar als docents. Recollida la informació és realitza una anàlisi de les produccions escrites i es relaciona amb els resultats de l'enquesta.

Paraules clau: Ilenguatge de missatgeria instantània, influència escriptura, tauleta, escriptura a mà, educació primària.

\section{Abstract}

This dissertation has the aim to provide new knowledge about one of the actual problems related to the educational world and the linguistic area that has a greater impact, the instant messaging language. Therefore, the investigation is firstly focused on knowing the state of the matter; secondly, on identifying if pupils of sixth of Primary have an influence of this type of language in their handwriting, which is the reason of the investigation. Finally, assessing whether there is any influence and which features it has. Several research activities are conducted written expression

\footnotetext{
${ }^{a}$ Col-legi Diocesà Sagrada Família de Tortosa

b Universitat Rovira i Virgili

c Universitat Rovira i Virgili
} 
using ICT and handwriting. Once collected the information we proceed to analyze the elaborate texts and the information gathered in the inquests.

Keywords: instant messaging language, influence writing, tablet, handwriting, primary education.

\section{Introducció}

Les tecnologies de la informació i comunicació (TIC) són una eina que revoluciona, en molts sentits, diferents camps, un d'ells la comunicació. Són un fet dinàmic ja que les innovacions tecnològiques avancen a un ritme trepidant $\mathrm{i}$, cada dia, apareixen noves aplicacions i nous serveis.

Els joves són els qui d'una manera més ràpida i intuïtiva, han aprés a utilitzar les TIC de moltes maneres diferents; però principalment aquestes s'han convertit en uns mitjans d'entreteniment i unes eines hàbils per a la socialització (Bringué i Sábada, 2009). S'estima que aproximadament el 50\% dels nens i nenes entre 11 i 12 anys són usuaris d'alguna xarxa social (Bringué i Sábada, 2011).

És innegable el fet que el jovent està ben equipat tecnològicament i té un domini força ampli dels aparell i sistemes. Segons les dades extretes de l'Institut Nacional d'Estadística de l'any 2013, podem observar que el 93,8\% dels nois i noies d'entre 11 i 12 d'anys utilitza l'ordinador, el 90,45\% fa ús d'Internet i el 50,2\% disposa de telèfon mòbil.

"La influència del llenguatge de missatgeria instantània en l'alumnat de 6è de Primària" és una investigació que pretén fer una anàlisi de la possible influència que pugui tenir l'alumnat de 6è de Primària dels codis que s'utilitzen en els llenguatge de missatgeria instantània. Els lingüistes i educadors estan cada cop més preocupats per l'evolució que està tenint el llenguatge, causada entre altres, per l'ús de múltiples abreviacions i alteracions lingüístiques utilitzades en les xarxes socials i altres mitjans relacionats en les TIC.

En referència al llenguatge, es pot afirmar que està evolucionant d'una manera tan ràpida en alguns àmbits que s'està perdent el control del seu ús, donant lloc a la creació d'alteracions del mateix. Així doncs, autors com Fernández, Fonseca, Schmidt i Vargas (2011) i Parrilla (2008) afirmen que les TIC, i especialment les xarxes socials, són el mitjà on les alteracions poden viure i desenvolupar-se.

Entre les alteracions més comunes del llenguatge de missatgeria instantània podem trobar (Galan, 2002, Levis, 2006, Parrilla, 2008 i Fernández, Fonseca, Schmidt i Vargas, 2011) unes coincidències:

- No es respecten les normes de puntuació, ni les ortogràfiques, ni les gramaticals.

- Desaparició de l'ús de l'accentuació de les paraules. 
- Ús de signes d'interrogació i exclamació al final de les oracions. La seva repetició marca èmfasi, també emfatitza afegir lletres al final dels mots. Exemple: "k fas???", "olaaaa!!", etc.

- Algunes paraules es canvien pel so de determinats signes matemàtics o xifres. Exemple: "per es canviat per x", "més es canviat per +", "adéu es canvia per $a 10^{\prime \prime}$, etc.

- $\quad$ Ús exclusiu de la lletra majúscula. Exemple: "KOM VA ANA LA FESTA?"

- Ús d'anglicismes, frases o abreviacions d'altres llengües. Exemple: "Ok", "thanks", "bye", etc.

- La vocals i consonants que es poden deduir desapareixen, com la "e" davant d'una "s", la "a" darrera d'una " $c$ ", la " $h$ " desapareix gairebé sempre. Exemple: "scriure", "ola", etc.

- Simplificació d'estructures segons el so, com les consonants dobles, les variants gràfiques de "qu" i " $c$ " per " $k$ ", la "gu" es transcriu com "w". Exemple: "kasa", "wapo", "pk", etc.

- Afegir lletres inexistents o altres estructures per amenitzar una conversa o donar un toc de lleugeresa al significat. Exemple: "okis", "sip", "jejeje", "jajajaja", etc.

- $\quad$ Ús d'emoticones. Exemple: "[:) ], [:(], [;)]", etc.

Un cop observades les característiques anteriors, es pot arribar a la conclusió que la nova forma d'escriptura busca l'esquematització i la simplificació per tenir més rapidesa a l'hora de redactar, reduir l'espai emprat i l'originalitat per produir formes creatives del llenguatge per fer més divertida i flexible la comunicació. Aquest fenomen del llenguatge de missatgeria instantània tindrà, com ja manifesten certs autors, possibles conseqüències en l'aspecte lingüístic, en els hàbits de lectura i escriptura i en l'aspecte socio-comunicatiu.

Pel que fa a l'aspecte lingüístic, es pot dir que hi ha hagut un fort increment de la comunicació escrita, és a dir, s'està escrivint molt més que abans, però, al mateix temps, es destaca un empobriment de la llengua pel que fa al vocabulari i augmenten les errades ortogràfiques i gramaticals (Orihuela, 2006, citat a Parrilla, 2008). Relacionat amb la temàtica, hi ha autors que exposen que aquells joves que no tinguin l'ortografia ben assolida, un ús abusiu de les alteracions perjudicarà més el seu llenguatge, per tant, portarà confusions i a no saber distingir en quins contextos és adequat utilitzar aquest llenguatge i en quins no (Yus, 2002, citat a Parrilla, 2008). L'hàbit de lectura i escriptura també ha augmentat una mica ja que la major part de les noves tecnologies i les telecomunicacions implica la lectura i, conseqüentment, l'escriptura. Finalment, en l'àmbit socio-comunicatiu destaca l'increment de les comunicacions però sense donar-los gaire rellevància, ja que manquen les habilitats 
socials a I'hora de relacionar-se de forma presencial. Tot i així podem dir que les persones són més lliures utilitzant aquests nous canals de comunicació (Levis, 2006).

Així doncs, l'ús de les TIC, de les xarxes socials i dels sistemes de missatgeria instantània han facilitat les alteracions del llenguatge. Recordem, però, que no són els mitjans (els SMS, TIC o xarxes socials) qui han desenvolupat aquestes modificacions del llenguatge sinó les mateixes persones, usuàries dels serveis.

\section{Contextualització de la investigació}

L'estudi s'ha realitzat durant la segona meitat del curs escolar 2014/2015 en un centre d'educació infantil i primària de la ciutat de Tortosa (Baix Ebre).

\subsection{Objectius}

Els objectius que han guiat l'estudi són:

- Identificar si l'alumnat de 6è de Primària presenta alguna influència del llenguatge de missatgeria instantània en la seva escriptura.

- Observar i analitzar l'escriptura de l'alumnat de 6è de Primària en contextos diferents per determinar si presenten influència.

- Valorar si l'alumnat de 6è de Primària sap en quins contextos pot utilitzar el llenguatge de missatgeria instantània i en quins no.

- Determinar si el suport utilitzat a l'hora d'escriure influeix en el tipus de llenguatge utilitzat.

Les hipòtesis generades, i que posteriorment seran analitzades, són les següents:

- L'alumnat de 6è de Primària presenta una influència en la seva escriptura del llenguatge de missatgeria instantània.

- L'alumnat de 6è de Primària només utilitzà el llenguatge de missatgeria instantània en contextos informals.

- L'alumnat de 6è de Primària presenta un ús major del llenguatge de missatgeria instantània quan utilitza suports electrònics per escriure que no pas quan escriu a mà.

Tanmateix, és important descriure quines són les variables presents en aquesta investigació: 
- El llenguatge, fent referència al grau d'interiorització de llenguatge de missatgeria instantània.

- El suport, destacant en quins dels tres suports analitzats (tauleta tàctil, ordinador i a mà) hi ha més presència del llenguatge de missatgeria instantània.

El context, segons el context (formal o informal) en què es troba el subjecte hi ha més presència o menys del llenguatge de missatgeria instantània.

\subsection{Metodologia}

Aquesta recerca és descriptiva ja que el seu objectiu és explicar fenòmens i les seves relacions, en un abast temporal de tipus transversal. És una metodologia qualitativa perquè s'orienta a descriure i interpretar un fenomen social $i$, alhora, educatiu i on les intencions de les accions humanes, analitzades des d'una perspectiva social, són molt importants; tot i així utilitza també instruments quantitatius de recollida de dades.

\subsubsection{Població i mostra}

S'ha definit una mostra de tipus casual o mostra per accessibilitat de l'alumnat de 6è de Primària. Aquesta població seleccionada mitjançant mostreig no probabilístic engloba un conjunt de 90 subjectes pertanyents a una escola pública de Tortosa amb quatre línies de segon curs de Cicle Superior, així com al professorat del centre.

\subsubsection{Instruments de recollida de dades}

En la recerca es combinen diferents tècniques de recollida de dades amb la finalitat de realitzar una investigació el més completa possible: I'anàlisi de text i l'enquesta, una a la mostra i l'altra al professorat.

Mitjançant l'anàlisi de text s'analitzen les converses escrites entre els subjectes de la mostra amb l'objectiu de buscar unes determinades peculiaritats en la seva escriptura quotidiana. S'enregistren converses de manera telemàtica i es realitza una anàlisi a posteriori. També es procedeix a la recollida de produccions escrites a mà per analitzar l'ús del llenguatge en els diferents suports (tauleta tàctil, ordinador i manuscrit).

L'activitat consisteix en crear grups de conversa en una aplicació de "Google +", concretament, la xarxa social "Hangouts" i afegir als subjectes en grups petits (quatre grups de cinc o sis subjectes) per fomentar i facilitar la comunicació entre aquests tal i com es produeix en altres entorns més quotidians. Seguidament, s'introdueix un tema (missatges inicials) a partir del qual els subjectes han d'aportar les seves idees i, 
per tant, escriure. Per poder tenir en compte les variables del suport en la investigació, en aquesta pràctica s'introdueix el fet que els subjectes han de participar en les converses utilitzant suports diferents. Dos grups realitzaran l'activitat en suport tauleta tàctil i els altres grups ho faran utilitzant l'ordinador. En sessions posteriors es farà a la inversa, es canviaran els suports dels grups, això permetrà valorar si el suport que s'utilitza a l'hora d'escriure influeix en el tipus de llenguatge utilitzat, ja que no és el mateix escriure quan disposes d'un teclat com el de l'ordinador que quan s'escriu en el teclat de la pantalla d'un mòbil o tauleta tàctil. Finalment, per analitzar si la influència del llenguatge de missatgeria instantània va més enllà del suport tecnològic, també es demana als subjectes la redacció d'una petita composició escrita a mà.

L'altre instrument emprat és l'enquesta, una destinada a l'alumnat i una altra de diferent per als docents del centre. Ambdues es caracteritzen per ser combinades, és a dir, descriptives (conèixer i descriure característiques), explicatives (contrastar hipòtesis), transversals (recollir informació d'un període de temps delimitat i no d'un procés evolutiu) $i$, finalment, són prospectives (estudiar els fets al mateix moment que estan passant). L'eina utilitzada per recollir la informació són els Formularis de Google. Aquest instrument, completat pels alumnes i tutors/es de cada grup serveix per contrastar opinions i permet tenir en compte la seva perspectiva.

\section{Anàlisi dels resultats i interpretació}

Els resultats obtinguts permetent realitzar una anàlisi i interpretació amb la finalitat d' extreure unes conclusions que seran les que generaran un nou coneixement. En primer lloc es valoraran els resultats de la primera tècnica de recollida de dades, és a dir, l'anàlisi de textos. Seguidament es farà un buidatge i es quantificaran les dades de les enquestes passades a la mostra i, per acabar, s'extrauran les opinions i idees principals a partir de les enquestes realitzades als tutors i tutores dels/les alumnes de mostra.

\subsection{Anàlisi de textos}

Aquest primer apartat està destinat a observar i analitzar les produccions o els textos (també converses) que la mostra ha realitzat especialment per aquesta investigació.

\section{CONVERSES}

\begin{tabular}{|l|l|}
\hline \multicolumn{2}{|c|}{ GRUP A-SUBGRUP 1} \\
\hline TAULETES TÀCTILS & ORDINADOR \\
\hline G. M. - 16:09 & $\begin{array}{l}\text { G. } \text { M. }-16: 42 \\
\text { Ola }\end{array}$ \\
\hline $\begin{array}{l}\text { S. } \text { E. T. }- \text { 16:14 } \\
\text { Vui di a manhester }\end{array}$ & A. T. P. - 16:44 \\
\hline
\end{tabular}




\begin{tabular}{|l|l|}
\hline Jajaj & \\
\hline S. E. T. - 16:14 & $\begin{array}{l}\text { A. T. P. - 16:45 } \\
\text { jooooooo vuuuuuulll annnaaarr aaaa } \\
\text { mmmaaaaadddriiiddd } \\
\text { jijijijijijjijijijijijiji }\end{array}$ \\
\hline $\begin{array}{l}\text { A. T. P. - 16:18 } \\
\text { Noooooooooo }\end{array}$ & $\begin{array}{l}\text { A. T. P. - 16:46 } \\
\text { i tb magradaria annar a londres!!!!!!!!! }\end{array}$ \\
\hline $\begin{array}{l}\text { G. M. - 16:35 } \begin{array}{l}\text { Ola parlo sic ivan } \\
\text { Soc } \\
\text { Eeeeeeeeeeoooooooo }\end{array} \\
\text { ok }\end{array}$ \\
\hline
\end{tabular}

Taula 1. Producció Grup A Supgrup 1. Font: Elaboració pròpia a partir de les dades aportades per l'alumnat.

\begin{tabular}{|c|c|}
\hline \multicolumn{2}{|c|}{ GRUP A-SUBGRUP 2} \\
\hline TAULETES TÀCTILS & ORDINADOR \\
\hline $\begin{array}{l}\text { P. A. - 15:57 } \\
\text { Holaaa }\end{array}$ & $\begin{array}{l}\text { N. C. F. - 16:36 } \\
\text { jijijijijiji }\end{array}$ \\
\hline $\begin{array}{l}\text { P. A. - 15:57 } \\
\text { Q??? } \\
\text { (i):): }\end{array}$ & $\begin{array}{l}\text { M. L. - 16:38 } \\
\text { ??????????????? }\end{array}$ \\
\hline $\begin{array}{l}\text { P. A. - 15:58 } \\
\text { Marc } \\
\text { Dkp???!?!?!?!? }\end{array}$ & $\begin{array}{l}\text { A. M. - } 16: 42 \\
\text { media hora mas tarde me deja } \\
\text { entrar }\end{array}$ \\
\hline $\begin{array}{l}\text { A. T. - 15:59 } \\
\text { Nooooooo0000000000 }\end{array}$ & $\begin{array}{l}\text { Paula Ad - } 16: 42 \\
\text { De k anireu disfressats al carnaval? }\end{array}$ \\
\hline $\begin{array}{l}\text { A. T. - } 15: 59 \\
\text { (ब) }\end{array}$ & $\begin{array}{l}\text { P. A. - } 16: 44 \\
\text { esq nuse...... }\end{array}$ \\
\hline $\begin{array}{l}\text { P. A. - 15:59 } \\
\text { Oki }\end{array}$ & $\begin{array}{l}\text { P. A. }-16: 45 \\
\text { pero totes les cançons q diem serviran d } \\
\text { algo?????? } \\
\text { i feel good }\end{array}$ \\
\hline $\begin{array}{l}\text { N. C. F. - 15:59 } \\
\text { perk no ha acceptat la invitacio }\end{array}$ & $\begin{array}{l}\text { M. L. - 16:53 } \\
\text { bye,bye } \cong \approx \approx\end{array}$ \\
\hline $\begin{array}{l}\text { A. T. - } 16: 00 \\
\text { Ps no se }\end{array}$ & \\
\hline
\end{tabular}




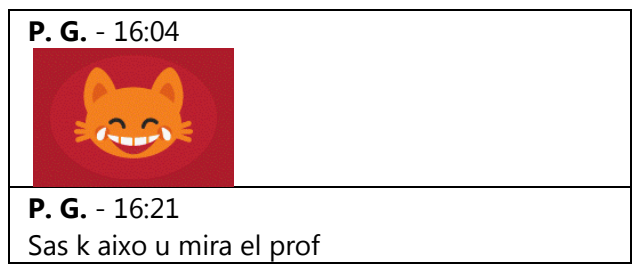

Taula 2. Producció Grup A Supgrup 2. Font: Elaboració pròpia a partir de les dades aportades per l'alumnat

\begin{tabular}{|c|c|}
\hline \multicolumn{2}{|c|}{ GRUP A-SUBGRUP 3} \\
\hline ORDINADOR & TAULETES TÀCTILS \\
\hline $\begin{array}{l}\text { C. C. - 16:15 } \\
\text { perk? } \\
\text { t'agradaria anar allí Georgina? }\end{array}$ & $\begin{array}{l}\text { A. P. }-16: 32 \\
\text { K tal va }\end{array}$ \\
\hline $\begin{array}{l}\text { C. C. }-16: 16 \\
\text { aaaaaahhhhh...... } \\
\text { mol b }\end{array}$ & $\begin{array}{l}\text { A. } \mathbf{P} .-16: 33 \\
\text { Jo vull anar d vacacions al pirineu a una } \\
\text { casa de colonies i anar a eskiar }\end{array}$ \\
\hline $\begin{array}{l}\text { G. C. B. } 16: 18 \\
\text { tmb podriem anar a puestos on } i \text { aguesin } \\
\text { coxonetes }\end{array}$ & $\begin{array}{l}\text { A. P. - } 16: 35 \\
\text { No estic aki } \\
\text { Ki es lo k no te foto }\end{array}$ \\
\hline $\begin{array}{l}\text { A. P. - } 16: 21 \\
\text { framfurs nyam }\end{array}$ & A. P. - $16: 41$ \\
\hline $\begin{array}{l}\text { A. P. - } 16: 22 \\
\text { es k tens k posar hahahahaha }\end{array}$ & $\begin{array}{l}\text { A. E.- 16:44 } \\
\text { Holi }\end{array}$ \\
\hline
\end{tabular}

Taula 3. Producció Grup A Supgrup 3. Font: Elaboració pròpia a partir de les dades aportades per l'alumnat.

\begin{tabular}{|c|c|}
\hline \multicolumn{2}{|c|}{ GRUP A-SUBGRUP 4} \\
\hline ORDINADOR & TAULETES TÀCTILS \\
\hline $\begin{array}{l}\text { I. B. - } 16: 18 \\
\text { ola } \\
\text { ia algu o que??? }\end{array}$ & $\begin{array}{l}\text { I. B. - 16:35 } \\
\text { Ola }\end{array}$ \\
\hline $\begin{array}{l}\text { C. F. A. - } 16: 20 \\
\text { qui?????? } \\
\because \because \because \because \because\end{array}$ & H. S. - $16: 45$ \\
\hline $\begin{array}{l}\text { H. S. - 16:23 } \\
\text { jejjejejjejejjejejje }\end{array}$ & $\begin{array}{l}\text { I. B. - } 16: 46 \\
\text { Olaaaaaaaa } \\
\text { Cinta estas o ke }\end{array}$ \\
\hline $\begin{array}{l}\text { I. B. - } 16: 32 \\
\text { cintaaaaaa }\end{array}$ & $\begin{array}{l}\text { C. F. A. - 16:52 } \\
\text { a10 }\end{array}$ \\
\hline
\end{tabular}

Taula 4. Producció Grup A Supgrup 4. Font: Elaboració pròpia a partir de les dades aportades per l'alumnat. 


\subsubsection{Anàlisi de les produccions escrites del grup a}

Un cop observat alguns fragments de les converses seleccionats per la varietat del llenguatge de missatgeria instantània que apareix, s'analitzaran detalladament totes les estructures per identificar aquelles característiques comunes amb aquest llenguatge. S'ha fet el següent anàlisi:

- Supressió de lletres insonores o que es sobreentenen, com la $h$ en paraules com "ola" la $r$ en "di", "mol b", "esq", "q", "perk", "ia" enlloc de hi ha, "d", "u" enlloc de ho, "Sas", "Ps".

- Simplificació d'estructures a partir d'utilitzar lletres que representen el mateix so, per exemple: "Ki", "a10", "aki", "eskiar", "ke", etc.

- Ús d'abreviacions com: "tb" enlloc de també o "pk" enlloc de perquè, "prof" per professor, "Dkp" substitueix a de què parlem, etc.

- Repetició d'estructures o allargar el final de les paraules per emfatitzar "olaolaolaoal", "Noooooooooo", "Olaaaaaaaa", "mmmaaaaadddrriiiddd", "cintaaaaaa", etc.

- Ús repetitiu de signes d'exclamació i interrogació per emfatitzar l'oració o la qüestió: "...serviran d algo??????", "Dkp???!?!?!?!?", "qui?????'”, "...a londres!!!!!!!!!", etc.

- Ús d'anglicismes com: "ok" i "really", "bye", etc.

- Desaparició de les regles d'accentuació, "adeuuuuuu", "pero", "algu", "colonies", "invitacio", "aixo", etc.

- Ús d'emoticones que expressen diferent tipologia d'emocions. Esmentar el fet d'afegir imatges.

- Afegir lletres inexistents amb l'objectiu de fer més amena la conversa o suavitzar el significat: "Holi", "oki", etc.

- Ús de l'estructura "jijiji", "jajaja", etc. per amenitzar la conversa.

Es pot observar que la gran majoria de les característiques esmentades anteriorment es localitzen en l'escriptura utilitzada en ambdós suports d'igual manera.

\begin{tabular}{|c|c|}
\hline \multicolumn{2}{|c|}{ GRUP B-SUBGRUP 1} \\
\hline TAULETES TÀCTILS & ORDINADOR \\
\hline \multirow{3}{*}{$\begin{array}{l}\text { D. H. V. - } 16: 19 \\
\text { Taz fa mo,lt sensevoremos } \\
\text {,-) :-) :-) :-) :-) :-) :-) :-) :-) :-) :-) :-) }\end{array}$} & L. G. C. - 16:33 \\
\hline & Ola \\
\hline & $\begin{array}{l}\text { L. G. C. - 16:36 } \\
\text { Nooo }\end{array}$ \\
\hline $\begin{array}{l}\text { L. G. C. - 16:19 } \\
\text { Q??? }\end{array}$ & $\begin{array}{l}\text { L. G. C. - } 16: 36 \\
\text { Sc jeni pero en lo correu de laia }\end{array}$ \\
\hline
\end{tabular}




\begin{tabular}{|l|l|}
\hline & Ok \\
\hline $\begin{array}{l}\text { L. N. C. R.- 16:21 } \\
\text { Bueno siii }\end{array}$ & $\begin{array}{l}\text { A. } \text { K. }-16: 40 \\
\text { ssssssssssssssssiiiiiiiiiiiiiiii } \\
\text { nnoooo no que vaaa }\end{array}$ \\
\hline $\begin{array}{l}\text { D. H. V. - 16:23 } \\
\text { Esk soc especiaal iabdu i yassine }\end{array}$ & $\begin{array}{l}\text { A. Y. }-16: 41 \\
\text { (1). }\end{array}$ \\
\hline $\begin{array}{l}\text { L. G. C. - 16:25 } \\
\text { Pero...es lo q toca... }\end{array}$ & $\begin{array}{l}\text { L. A. }-16: 42 \\
\text { Si es veritat } \\
\text { Adeuuu }\end{array}$ \\
\hline
\end{tabular}

Taula 5. Producció Grup B Supgrup 1. Font: Elaboració pròpia a partir de les dades aportades per l'alumnat.

\begin{tabular}{|c|c|}
\hline \multicolumn{2}{|c|}{ GRUP B-SUBGRUP 2} \\
\hline ORDINADOR & TAULETES TÀCTILS \\
\hline $\begin{array}{l}\text { A. C. P. - 16:17 } \\
\text { jo ja estic bé! i tú? } \\
\text { heu fet els deures' } \\
\text { perdó! era una pregunta } \\
\text { Fouad, com es fan les emoticones(caretes)? }\end{array}$ & $\begin{array}{l}\text { J. M. S. - } 16: 35 \\
\text { tmb } \\
\text { soc laia ara }\end{array}$ \\
\hline $\begin{array}{l}\text { A. H. B. - 16:19 } \\
\text { enserio?? }\end{array}$ & $\begin{array}{l}\text { D. B. - } 16: 36 \\
\text { Ola k fas }\end{array}$ \\
\hline $\begin{array}{l}\text { A. C. P. - } 16: 23 \\
\text { Jenni, el teu nom es així? }\end{array}$ & $\begin{array}{l}\text { J. Ba. - } 16: 36 \\
\text { ja eu fet els deures } \\
\text { ():-) }\end{array}$ \\
\hline A. C. P. $-16: 25$ & $\begin{array}{l}\text { B. - } 16: 37 \\
\text { Beeeeeeeeeeeeeee }\end{array}$ \\
\hline $\begin{array}{l}\text { J. M. S.- 16:27 } \\
\text { jejej }\end{array}$ & $\begin{array}{l}\text { J. M. S - 16:39 } \\
\text { jaja } \\
\text { dina no entenc e de lo q escrius jaja } \\
\text { no de k }\end{array}$ \\
\hline $\begin{array}{l}\text { A. C. } \mathbf{P}-16: 27 \\
\text { i per que ho dius? }\end{array}$ & $\begin{array}{l}\text { J. M. S - 16:40 } \\
\text { jeje adeuu mon anem tots jiji } \\
\text { bnanittt }\end{array}$ \\
\hline $\begin{array}{l}\text { J. M. S - 16:27 } \\
\text { andreu tns mobil }\end{array}$ & $\begin{array}{l}\text { J. M. S - 16:40 } \\
\text { vle }\end{array}$ \\
\hline $\begin{array}{l}\text { A. C. } \mathbf{P}-16: 28 \\
\text { no tinc mobil, no }\end{array}$ & \\
\hline
\end{tabular}

Taula 6. Producció Grup B Supgrup 2. Font: a Elaboració pròpia a partir de les dades aportades per l'alumnat.

\subsubsection{Anàlisi de les produccions escrites del grup b}

- Supressió de lletres insonores o que es sobreentenen, per exemple: "tns" per tens, "k" o "q", "sc" enlloc de sóc, "vle" per vale, "tmb" enlloc de també, etc. 
- Repetició d'estructures o allargar el final de les paraules per emfatitzar "Beeeeeeeeeeeeeeee", "ssssssssssssssssiiiiiiiiiiiiiii", etc.

- Ús repetitiu de signes d'exclamació i interrogació per emfatitzar l'oració o la qüestió: "enserio??", "Q???", etc.

- Desaparició de les regles d'accentuació, "adeu", "mobil", "soc", etc.

- $\quad$ Ús d'emoticones que expressen diferent tipologia d'emocions.

- Ús d'anglicismes com: "ok", etc.

- U Ús de l'estructura "jijiji", "jejejeje", "jajaja", etc. per amenitzar la conversa.

- $\quad$ Unió de diferents paraules en un mateix conjunt, "enserio", "bnanittt", "Esk", etc.

- Cal destacar el cas de A.C.P. que en la majoria de les seves produccions ho escriu gairebé tot correcte; en la mateixa conversació, els/les companys/es li pregunten si disposa de telèfon mòbil segurament perquè noten que escriu d'una manera diferent i ell diu que no en té, per tant, això evidència que la seva influència del llenguatge és menor.

La gran majoria de les característiques esmentades anteriorment es localitzen en l'escriptura utilitzada en ambdós suports d'igual manera.

\begin{tabular}{|c|c|}
\hline \multicolumn{2}{|c|}{ GRUP C-SUBGRUP 1 i 2} \\
\hline ORDINADOR & TAULETES TÀCTILS \\
\hline $\begin{array}{l}\text { B. F. - } 16: 30 \\
\text { k feu? }\end{array}$ & $\begin{array}{l}\text { M. A. S. - } 16: 35 \\
\text { Ola }\end{array}$ \\
\hline $\begin{array}{l}\text { B. F - } 16: 31 \\
\text { olaaa okii }\end{array}$ & $\begin{array}{l}\text { N. C. E. - 16:36 } \\
\text { K faras lo cap de setmana }\end{array}$ \\
\hline $\begin{array}{l}\text { B. F - } 16: 32 \\
\text { de k parlem? }\end{array}$ & $\begin{array}{l}\text { A. S. - 16:39 } \\
\text { Jajjajaja }\end{array}$ \\
\hline $\begin{array}{l}\text { E. P. E. - 16:33 } \\
\text { no seeee }\end{array}$ & $\begin{array}{l}\text { A. S. - } 16: 42 \\
\text { Ok }\end{array}$ \\
\hline $\begin{array}{l}\text { E. P. E - } 16: 34 \\
\text { pero de k parlem'????????????? }\end{array}$ & $\begin{array}{l}\text { A. S. - } 16: 48 \\
\text { Manel dis on t'agradaria anar??? }\end{array}$ \\
\hline $\begin{array}{l}\text { N. C. E. - 16:37 } \\
\text { Ok }\end{array}$ & $\begin{array}{l}\text { A. S. }-16: 53 \\
\text { L what?? }\end{array}$ \\
\hline $\begin{array}{l}\text { E. P. E - 16:37 } \\
\text { de k de kkkkkkk }\end{array}$ & $\begin{array}{l}\text { N. C. E. - 16:55 } \\
\text { Ya..... }\end{array}$ \\
\hline $\begin{array}{l}\text { M. E. - 16:37 } \\
\text { ja }\end{array}$ & Dewwsww \\
\hline $\begin{array}{l}\text { B. F. - } 16: 38 \\
\text { a la k wai eva }\end{array}$ & A. S. $-16: 56$ \\
\hline $\begin{array}{l}\text { E. T. - } 16: 40 \\
\text { pq }\end{array}$ & \\
\hline
\end{tabular}




\begin{tabular}{|l|l|}
\hline M. R. L. - 16:45 & M. A. S. - 16:56 \\
EL DIUMENGE VAIG A DINAR A CASA DE LA & Adeuuuuuuuuu \\
MEVA IAIA EN LA MEVA PADRINA & \\
\hline $\begin{array}{l}\text { L. Z. - 16:53 } \\
\text { ps de lo q vulges } \\
\text { d lo q llegeise }\end{array}$ & \\
\cline { 1 - 1 } $\begin{array}{l}\text { N. C. E. - 16:54 } \\
\text { Contestaaaaaa....... }\end{array}$ & \\
\cline { 1 - 1 } $\begin{array}{l}\text { L. Z. - 16:56 } \\
\text { a dwwwww }\end{array}$ & \\
\hline
\end{tabular}

Taula 7. Producció Grup C Supgrup 1 i 2. Font: Elaboració pròpia a partir de les dades aportades per l'alumnat.

\subsubsection{Anàlisi de les produccions escrites del grup c}

- $\quad$ Supressió de lletres insonores o que es sobreentenen, com la $h$ en paraules com "ola", "ps", "q", "d" etc.

- Simplificació d'estructures a partir d'utilitzar lletres que representen el mateix so, per exemple: "dwwww", "deww", "wai", etc.

- Repetició d'estructures o allargar el final de les paraules per emfatitzar "dwww", "Contestaaaaa....", "Adeuuuuuuuuu".

- Ús repetitiu de signes d'exclamació i interrogació per emfatitzar l'oració o la qüestió: "pero de k parlem'????????????", "Manel dis on t'agradaria anar???", etc.

- Ús d'anglicismes com: "ok", "what", etc.

- Desaparició de les regles d'accentuació, "adeu".

- $\quad$ Ús d'emoticones que expressen diferent tipologia d'emocions.

- Afegir lletres inexistents per amenitzar la conversa o suavitzar el significat: "oki", etc.

- $\quad$ Ús de l'estructura "jajaja", etc. per amenitzar la conversa.

- $\quad$ Escriure en lletra majúscula, "EL DIUMENGE VAIG A DINAR A CASA..."

La gran majoria de les característiques esmentades anteriorment es localitzen en l'escriptura utilitzada en ambdós suports d'igual manera.

\section{TEXTOS ESCRITS A MÀ}

De totes les mostres recollides de produccions escrites, les següents són les úniques que presenten alguna petita característica que es compartida amb el llenguatge de missatgeria instantània. 


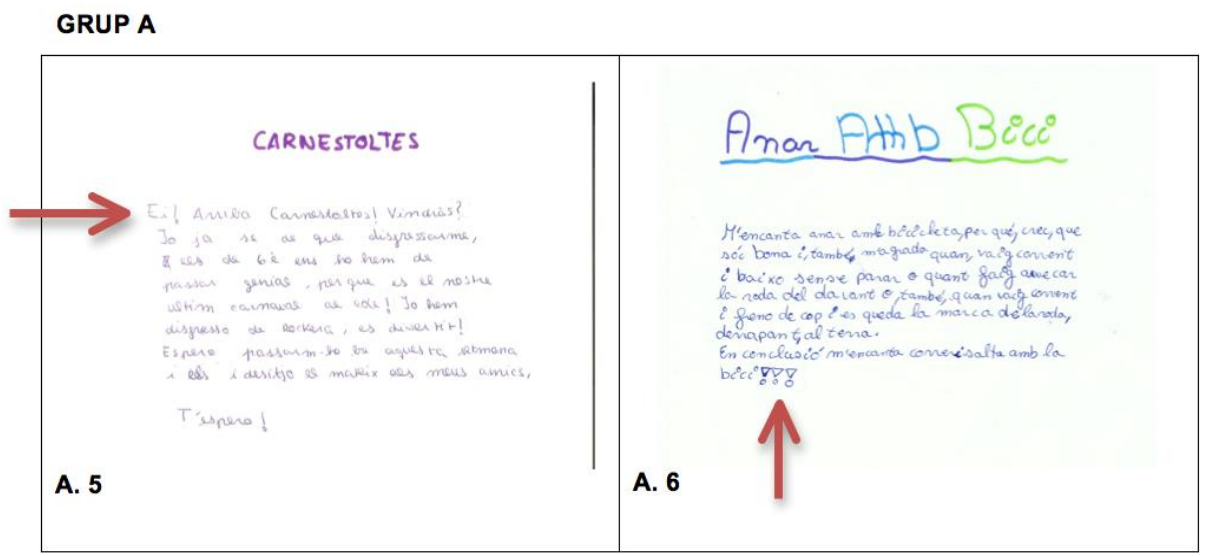

Figura 1. Producció A5 i A6. Font: Elaboració per part de l'alumnat.

\section{ANÀLISI DE LES PRODUCCIONS ESCRITES}

A la figura 1, a la mostra escrita de la producció A. 5 es pot observar una fórmula introductòria molt usual en la comunicació telemàtica, especialment, en contextos informals i utilitzant el llenguatge de missatgeria instantània. En canvi, en la producció A. 6 es pot identificar l'ús repetitiu del signe d'exclamació, en aquest cas, amb la finalitat d'emfatitzar el sentit de l'oració final. En la resta de produccions d'aquest grup no hi cap altra evidència.

GRUP B

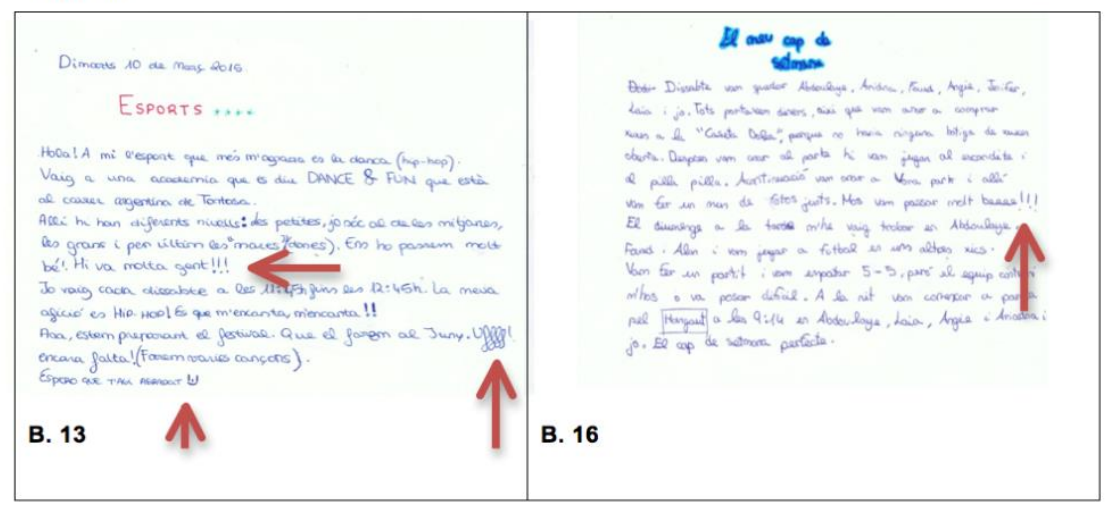

Figura 2. Producció B13 i B16. Font: Elaboració per part de l'alumnat.

\section{ANÀLISI DE LES PRODUCCIONS ESCRITES}

En la producció B. 13 (Figura 2), es poden identificar diferents elements. El primer, l'ús repetitiu del signe d'exclamació que si ens fixem en els tres casos que s'han observat 
a les diferents produccions, totes utilitzaven tres signes d'exclamació. En segon lloc hi ha l'expressió "uffff" que representa esforç o cansament, emfatitzada per l'ús repetitiu de la " $f$ ". I finalment, el text finalitza amb una emoticona dibuixada a mà que representaria la típica cara feliç. En la producció B. 16 del grup B, es pot veure un altre cop l'ús repetitiu del signe d'exclamació amb la mateixa funció.

\section{GRUP C}

No hi ha cap text escrit a mà del grup $C$ que presenti cap element del llenguatge de missatgeria instantània.

\subsubsection{Enquestes mostra}

La quantificació de les dades extretes de les quinze preguntes de l'enquesta són:

Pregunta 1: Disposes de telèfon mòbil o tauleta tàctil amb connexió a Internet?

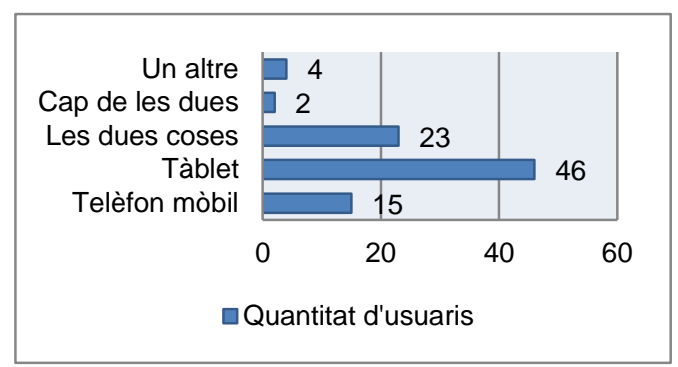

Figura 3. Resum de les respostes de la pregunta $n^{\circ} 1$ de I'enquesta a la mostra. Font: Elaboració pròpia.
Segons la Figura 3 observem que 46 usuaris disposen de tauleta tàctil i 15 de telèfon mòbil, per tant, el $61 \%$ dels enquestats disposa d'un aparell o un altre, el $26 \%$ gaudeix de tenir ambdós elements tecnològics; només 4 persones especifiquen l'opció d'un

altre, $\mathrm{i}$ especifiquen que tenen en tots els casos ordinadors; finalment només dues persones indiquen no

tenir cap element tecnològic a la seva disposició.

Podem arribar a la conclusió que la població de mostra està altament equipada tecnològicament ja que el $98 \%$ dels enquestats disposa d'algun element. Per tant, es pot afirmar d'entrada que disposen dels mitjans o suports necessaris per poder comunicar-se i utilitzar el llenguatge de missatgeria instantània. 
Pregunta 2: Quant de temps fa que tens telèfon mòbil o tauleta tàctil?

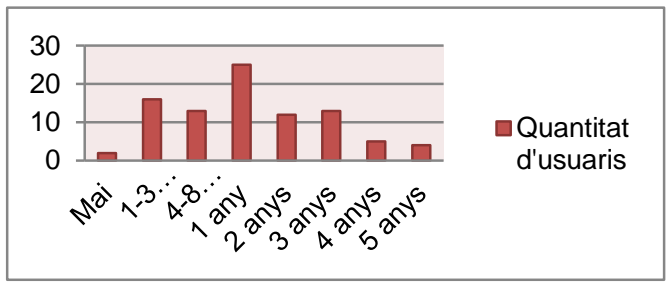

Figura 4. Resum de les respostes de la pregunta $n^{\circ}$ 2 de l'enquesta a la mostra. Font: Elaboració pròpia.
La Figura 4, recull les respostes que ha donat l'alumnat de la manera més aproximada possible, en períodes de temps. Una gran majoria d'alumnes disposen d'aquests aparells tecnològics des de fa poc temps, ja que més de la meitat dels enquestats (54 respostes) han respòs que Figura 6 .Resum de les respostes de la pregunta $\mathrm{n}^{\circ} 4$ de disposen dels aparells des de fa un any o menys. Un percentatge força significatiu ha respòs més d'un any. Cal destacar els 9 usuaris que han especificat més de 4 o 5 anys.

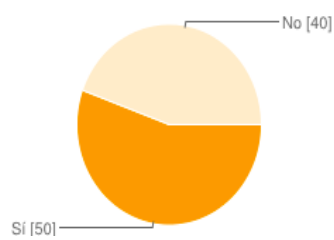

Figura 5. Resum de les respostes de la pregunta $n^{\circ}$ 3 de l'enquesta a la mostra. Font: Elaboració pròpia.

Pregunta 3: Utilitzes el mòbil o tauleta tàctil per enviar i rebre missatges de text?

En la pregunta $n^{\circ} 3$ (Figura 5) es destaca que el $56 \%$ ha respòs que sí envia i rep missatges de text i el $44 \%$ restant no. S'interpreta que més de la meitat dels usuaris sí que envien i reben missatges $i$, per tant, poden fer ús del llenguatge de missatgeria instantània.

Pregunta 4: Coneixes alguna xarxa social? Anomena-les.
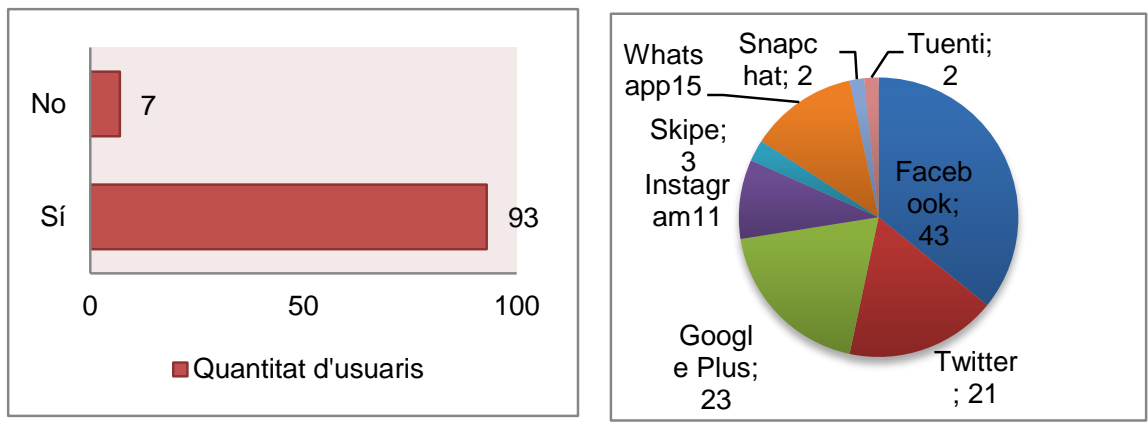

Figura 6 .Resum de les respostes de la pregunta $n^{\circ} 4$ de l'enquesta a la mostra.. Font: Elaboració pròpia. A la dreta, Figura 7 (Xarxes socials conegudes per la mostra). Font: Elaboració pròpia. 
La figura 6 mostra que el 93\% dels usuaris coneix alguna xarxa i el 7\% no. En la figura 7 hi ha un resum de les respostes més utilitzades, és a dir, representen el nombre de vegades que s'han especificat al qüestionari. Per tant, les opcions més nombrades són Facebook, Google + i Twitter. Cal destacar que hi ha hagut 15 usuaris que han dit WhatsApp, tot i així cal especificar que aquest és un servei de missatgeria instantània i no una xarxa social, per tant, no tothom sap el que és una xarxa social.

Pregunta 5: Estàs dins d'una xarxa social? Quant temps fa?
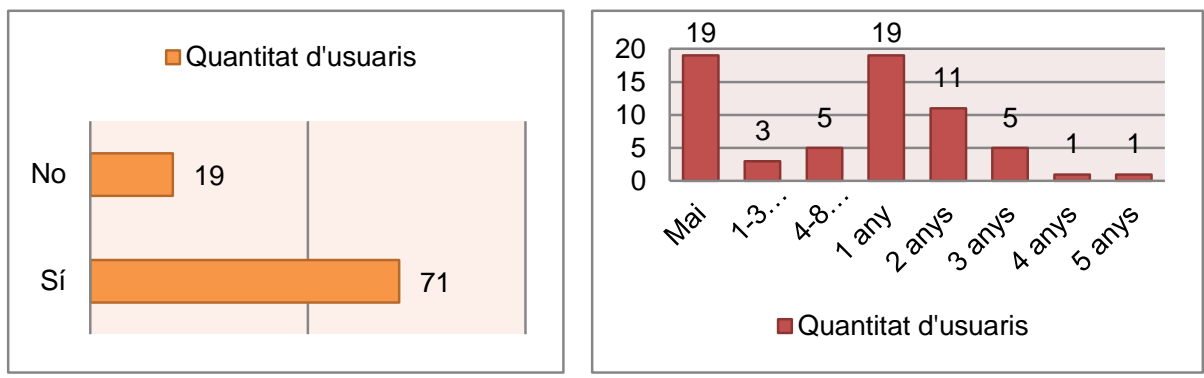

A l'esquerra, Figura 8. (Resum de les respostes de la pregunta $n^{\circ} 5$ de l'enquesta a la mostra). Font: Elaboració pròpia. A la dreta, Figura 9. (Temps que fa que estan dins les xarxes socials). Font: Elaboració pròpia.

La Figura 8 representa la quantitat d'enquestats que tenen un perfil dins d'una xarxa social o no en tenen. Mentre que la figura 9 especifica els temps que fa que tenen el perfil. S'interpreta que hi ha un percentatge força elevat que té un perfil majoritàriament a Facebook, Twitter, Google+ i també WhatsApp, sense ser xarxa social. Pel que fa al temps que tenen el perfil, majoritàriament fa entre un i dos anys, això condiciona el temps que han estat en contacte amb aquest llenguatge. Cal afegir que 26 enquestats, que han respòs que sí a la primera part de la pregunta, no han respòs la segona part.

Pregunta 6: Utilitzes les xarxes socials (Facebook, Twitter, Tuenti, Flickr, My space, Ning, etc.) per enviar i rebre missatges? Quines utilitzes?


A l'esquerra, Figura 10 (Resum de les respostes de la pregunta $n^{\circ} 6$ de l'enquesta a la mostra). Font: Elaboració pròpia. A la dreta, Figura 11 (Xarxes socials utilitzades per la mostra). Font: Elaboració pròpia. 
La Figura 10 representa el número d'enquestats que utilitzen alguna xarxa social per enviar i rebre missatges; mentre que la Figura 11 mostra quines són les xarxes a través de les quals envien i reben els missatges. És força probable que utilitzin el llenguatge de missatgeria instantània perquè més de la meitat dels enquestats envien i reben missatges. Les xarxes més utilitzades tornen a ser Facebook, Google+ a través de Hangout, ja que així ho han especificat i també WhatsApp.

Pregunta 7: Quants missatges de text envies en un dia laboral aproximadament?

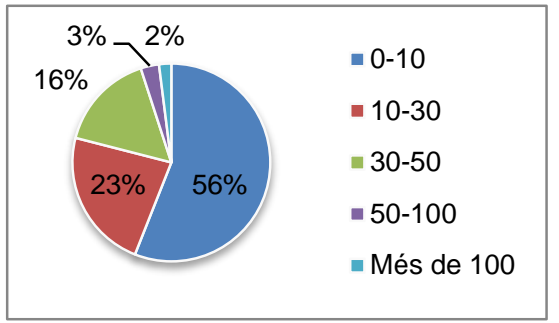

La Figura 12 mostra el percentatge de les opcions marcades pels enquestats sobre el número de missatges que envien en un dia laborable. Segon els resultats, més de tres quartes parts (79\%) envien menys de 30 missatges o no n'envia cap, mentre que el $21 \%$ n'envia més de 50 .

Figura 12. Resum de les respostes de la pregunta $n^{\circ} 7$ de l'enquesta a la mostra. Font: Elaboració pròpia.

Pregunta 8: Quants missatges de text envies en un dia de cap de setmana o festiu?

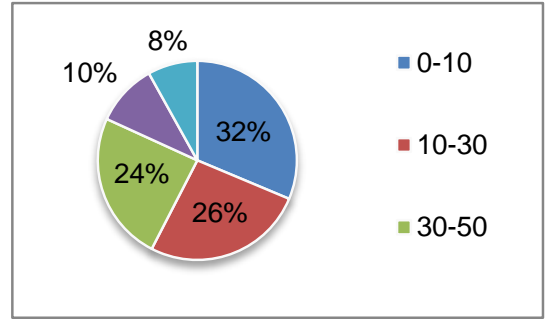

A la Figura 13, es pot veure si en un dia festiu augmenta el número de missatges enviats, i per tant, es pot concloure que sí. Més del $50 \%$ escriu menys de 30 missatges i gairebé l'altre $50 \%$ més de 30 missatges, tot destacant el $8 \%$ d'enquestats que n'escriuen més de 100 .

Figura 13. Resum de les respostes de la pregunta $\mathrm{n}^{\circ} 8$ de l'enquesta a la mostra. Font: Elaboració pròpia.

Pregunta 9: Marca algunes de les característiques de l'escriptura que utilitzes quan escrius un missatge de text?

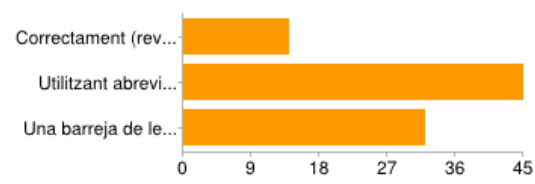

$\begin{array}{lll}\text { Correctament (revisant l'ortografia, puntuació...) } & \mathbf{1 4} & 16 \% \\ \text { Utilitzant abreviacions i emoticones } & \mathbf{4 5} & 50 \% \\ \text { Una barreja de les dues anteriors } & \mathbf{3 2} & 36 \%\end{array}$

Figura 14. Resum de les respostes de la pregunta $n^{\circ} 9$ de l'enquesta a la mostra. Font: Elaboració pròpia. 
La pregunta $n^{\circ} 9$ (Figura 14) tenia la finalitat d'esbrinar quin tipus de llenguatge utilitzen els enquestats quan escriuen un missatge de text. Els resultats indiquen que el 50\% utilitza el llenguatge basat en abreviacions i emoticones, el 36\% utilitza una mescla del llenguatge anterior però té en compte d'escriure mitjanament bé, i finalment, només un $16 \%$ té en compte escriure correctament.

Pregunta 10: Quan escrius un text per a l'escola (redacció, apunts, treballs, etc.) tens en compte totes les característiques pròpies d'un text adequat per a la situació (Coherència, cohesió, adequació, ortografia)?

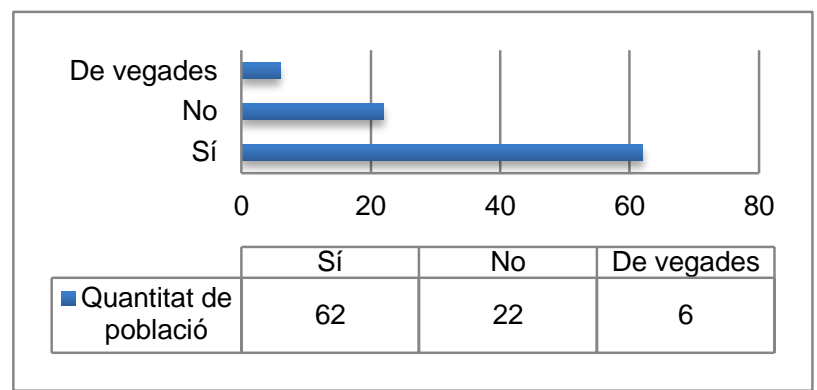

Figura 15. Resum de les respostes de la pregunta $n^{\circ} 10$ de l'enquesta a la mostra. Font: Elaboració pròpia.
L'objectiu de la pregunta (Figura 15) era conèixer si la mostra té en compte o no la utilització correcta de la llengua escrita en les seves produccions a l'escola. Es pot veure que 62 enquestats, que representa el 69\%, han dit que sí que tenen cura de les seves produccions

mentre que hi ha 22 enquestats que han respòs no, representant un 24\%. Tan sols 6 enquestats ha contestat que de vegades.

Pregunta 11: El llenguatge que utilitzes per escriure un missatge de text de WhatsApp, Facebook, Bloc... també l'utilitzes en altres contextos (escriure notetes, escriure apunts...)?

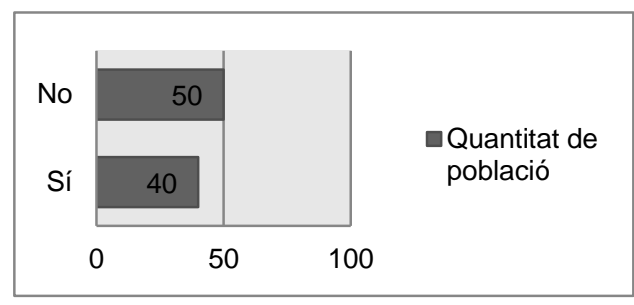

Figura 16. Resum de les respostes de la pregunta $n^{\circ}$ 11 de l'enquesta a la mostra. Font: Elaboració pròpia.

apunts i quan escriuen a l'ordinador.
Amb aquest pregunta (Figura 16) es volia esbrinar si la mostra utilitzava el llenguatge de missatgeria instantània en altres contextos més informals. $\mathrm{Hi}$ ha hagut 50 enquestats que han dit que no, que correspon a més de la meitat (56\%) i l'altre percentatge (44\%) constituït pels 40 que han respòs afirmativament, especificant que els altres contextos són notetes, 
Pregunta 12: Creus que el llenguatge que utilitzes als missatges de text o a les xarxes socials afecta negativament la teva expressió escrita?



Figura 17. Resum de les respostes de la pregunta $\mathrm{n}^{\circ} 12$ de l'enquesta a la mostra. Font: Elaboració pròpia.

i una minoria del $8 \%$ ha dit que molt.

$\begin{array}{lrr}\text { Gens } & \mathbf{2 5} & 28 \% \\ \text { Poc } & \mathbf{4 4} & 49 \% \\ \text { Bastant } & \mathbf{1 4} & 16 \% \\ \text { Molt } & \mathbf{7} & 8 \%\end{array}$

Pregunta 13: Quines conseqüències a llarg termini creus que pot provocar l'abús del llenguatge que utilitzes en els missatges de text? Enumera alguns exemples:

Aquesta qüestió tenia una resposta més oberta ja que els enquestats havien de pensar en les conseqüències de l'abús del llenguatge de missatgeria instantània. Per analitzar aquesta pregunta a continuació hi ha un recull de les respostes més comunes que han especificat.

\begin{tabular}{|l|l|l|}
\hline Acostumar-se a escriure així & $\begin{array}{l}\text { No saber com escriure una } \\
\text { paraula correctament }\end{array}$ & $\begin{array}{l}\text { Portar-te confusions a l'hora } \\
\text { d'escriure }\end{array}$ \\
\hline Empitjorar l'ortografia & $\begin{array}{l}\text { Fer sempre faltes } \\
\text { d'ortografia }\end{array}$ & $\begin{array}{l}\text { Cometre errors als exàmens, } \\
\text { escrits, etc. }\end{array}$ \\
\hline $\begin{array}{l}\text { Utilitzar aquest llenguatge } \\
\text { en contextos inapropiats }\end{array}$ & $\begin{array}{l}\text { No entendre correctament } \\
\text { el que vols transmetre o el } \\
\text { que vol dir l'altra persona }\end{array}$ & Destruir la llengua \\
\hline No posar accents & $\begin{array}{l}\text { Equivocar-te quan escrius } \\
\text { paraules com: que, hola, } \\
\text { adéu... }\end{array}$ & Oblidar l'ús de la gramàtica \\
\hline Confondre lletres & Ninguna & No ho sé \\
\hline
\end{tabular}

Taula 8. Recull d'algunes de les respostes de la pregunta $n^{\circ} 13$ de l'enquesta a la mostra. Font: Elaboració pròpia.

Pregunta 14: Transcriu l'oració següent utilitzant el llenguatge de missatgeria instantània. (-Hola! Què fas? Com estàs? Jo estic molt bé! Vols que quedem a la tarda per anar a berenar?)

Les qüestions 14 i 15 tenien l'objectiu d'avaluar si la mostra és capaç d'utilitzar el llenguatge de missatgeria instantània. Per això, aquí se'ls planteja convertir una 
oració típica d'una conversació en una frase escrita amb l'altra tipologia de llenguatge.

A continuació hi ha una mostra d'algunes de les oracions transcrites pels enquestats:

\begin{tabular}{l}
\hline $\begin{array}{l}\text { eiii!!ktal??saps k ja tin wasap!Jejejeje k waiiii estik mol contennnn!!!!Ara ia podrem parla kada } \\
\text { dia! dew }\end{array}$ \\
\hline Ola!ke fas? Com estas? Jo estic be! Vols k kedem a la tarde per ana a berena? \\
\hline Hla!q fas?cm stas?jo stic m b!vls q qdm a la trda pr na a \\
\hline $\begin{array}{l}\text { Olaa!!!!!!! Que have???? Com estas???? El menda esta molt be!!!!! Vols que quedecem per a } \\
\text { berenar??? }\end{array}$ \\
\hline ola k ase?com estas? jo estic guai . vols quedar a la tarde a berena \\
\hline hla! q fs? cm estas? jo estic mb!vls q quedem a la tde pr anar a berenar? \\
\hline $\begin{array}{l}\text { Oliiis!!!!!!(caretes)K fas ?????Com etas????Yo etic molt bee (caretes)!!!!Vols k kedem a LA trade } \\
\text { pera verenar ??? }\end{array}$ \\
\hline HI!Qf??Cm,este???J esic mb,VI k qdm a la trd $\mathrm{p}$ anr a brna \\
\hline
\end{tabular}

Taula 9. Recull d'algunes de les respostes de la pregunta $n^{\circ} 14$ de l'enquesta a la mostra. Font: Elaboració pròpia.

Després de veure alguns exemples, s'observa que els enquestats coneixen i utilitzen el llenguatge de missatgeria instantània en les seves varietats i formes diferents. Algunes de les característiques que destaquen són: desaparició de l'accentuació, ús abusiu dels signes d'interrogació i admiració per donar força al missatge, ús d'emoticones, ús d'abreviacions, desaparició de les lletres que no sonen, etc.

Pregunta 15: Transcriu l'oració següent de manera correcta, seguint les normes de coherència, cohesió, adequació i ortografia correctament. (-eiii!! K tal?? Saps k ja tin wasap! Jejejeje k waiiii estik mol contennnn!!!! Ara ia podrem parla kada dia! Dew)

Anomenat l'objectiu d'aquesta pregunta en la qüestió anterior, només afegir que en aquest s'havia de procedir a la inversa que abans.

A continuació hi ha una mostra d'algunes de les oracions transcrites pels enquestats:

Hola! Què tal? Saps que ja tinc whatsapp! Estic molt contenta!! Ara ja podrem parlar cada dia! Adeu

Eyyy!!que tal??saps que ja tinc whatsapp!jejejeje que guayyyy estic molt content!!!! Ara ja podrem parlar cada día!adeu

Hola! Què fas? Saps que ja tinc watsapp? Jeje, que guai estic molt content! Ara ja podrem parlar cada dia! Adéu.

Ei!! Què tal?? Saps que ja tinc Whatsapp! Jejejeje que guay estic molt content!!!! Ara ja podrem parlar cada dia! Adéu.

Ei ! Que tal ? Saps que ja ting wasap ! Jajajaja que guai estic molt content ! Ara hi ha podrem parlar cada dia ! ADEU ;) $<3$ 
iii!! que tal??Saps que ja tinc watssap!jejjejeque guai estic molt content!!!!!!!!!!!! .Ara ja podrem parlar cada dia !adeu

Hei que tal !Saps que ja tinc wattsapp!jejejeje que waiiiii estic molt content!!!!!!!ARA la podem parla cada día adeu

eii $k$ tal saps $k$ ya tink watasap jjjjjjj k wai estik molt content ara ia podem parlar cada dia......dw

Taula 10. Recull d'algunes de les respostes de la pregunta $n^{\circ} 15$ de l'enquesta a la mostra. Font: Elaboració pròpia.

$\mathrm{Hi}$ ha exemples que estan escrits correctament, n'hi ha moltes que estan escrits de manera correcta però amb faltes ortogràfiques o de puntuació, però també hi ha hagut altres que han escrit alguna peculiaritat del llenguatge de missatgeria instantània, com per exemple: jejejeje, jijiji, formes abreviades ( $d w$, k, wai) o l'ús repetitiu dels signes d'admiració i d'interrogació. Això demostra que a pesar de tenir la tasca d'escriure l'oració correctament, hi hagut qui, possiblement sense donar-se'n compte, ha mostrat la seva influència del llenguatge de missatgeria instantània.

\subsubsection{Enquestes mestres}

Pregunta 1: Què opines sobre l'ús del llenguatge de missatgeria instantània com una nova manera de comunicació?

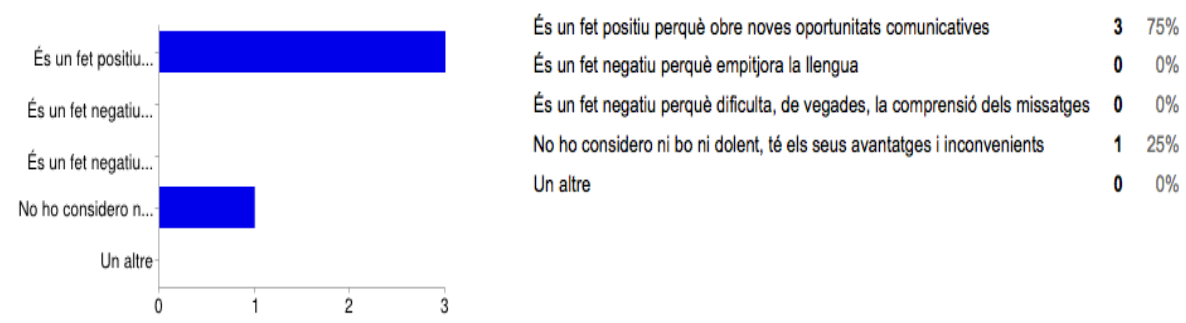

Figura 18. Resum de les respostes de la pregunta $n^{\circ} 1$ de l'enquesta als mestres. Font: Elaboració pròpia.

En la figura 18, que recull un resum de les respostes, la majoria dels docents han respòs la primera opció perquè ho veuen com un fet positiu que permet obrir noves oportunitats en l'àmbit de la comunicació i només un no ho valora ni com a positiu ni negatiu. Es pot entreveure que els docents veuen noves vies de comunicació i treball amb els seus avantatges i inconvenients.

Pregunta 2: Quin creus que és el nivell d'equipament tecnològic del teu alumnat? Per què ho creus? 


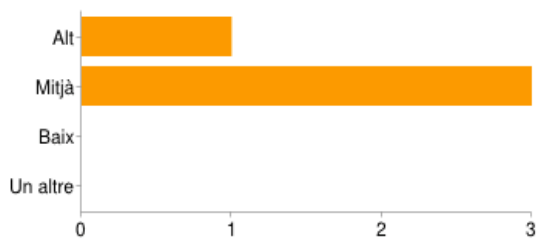

Figura 19. Resum de les respostes de la pregunta $n^{\circ} 2$ de l'enquesta als mestres. Font: Elaboració pròpia.

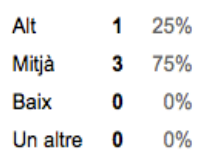

Es pot observar en la figura 19 que la consideració que té el professorat és d'un nivell mitjà-alt d'equipament tecnològic, cosa que coincideix amb la realitat, així es pot

contrastar en la pregunta 1 de l'enquesta a la mostra.

Pregunta 3:_Creus que el teu alumnat coneix i utilitza el llenguatge de missatgeria instantània?

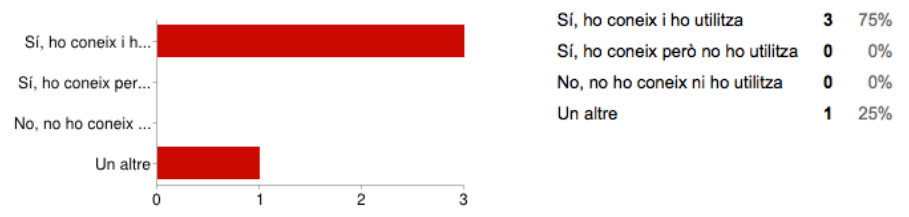

Figura 20. Resum de les respostes de la pregunta $n^{\circ} 3$ de l'enquesta als mestres. Font: Elaboració pròpia.

$\begin{array}{lr}\text { El } 100 \% & \text { del } \\ \text { professorat } & \\ \text { coincideix } & \text { que } \\ \text { l'alumnat coneix i } \\ \text { utilitza } & \text { el } \\ \text { llenguatge } & \text { de } \\ \text { missatgeria } & \\ \text { instantània. El }\end{array}$

El $100 \%$ del professorat coincideix que l'alumnat coneix i utilitza el missatgeria instantània. El

docent que va respondre "un altre", especifica que el coneixen i I'utilitzen, però no tant com una persona adulta. Es pot observar a la figura 20.

Pregunta 4: Què penses sobre el fet que els nens/es utilitzin les xarxes socials, xats o altres tecnologies semblants?

En aquesta pregunta oberta, cal destacar que tres dels quatre docents ho consideren positiu, sempre i quant, en facin un bon ús i no resti temps a altres activitats importants. També opinen que el docent ha d'acompanyar a l'alumnat en l'aprenentatge d'aquests espais per potenciar els aspectes positius i treballar amb eines noves, motivadores i evitar mals usos. La majoria creuen en la necessitat de la supervisió d'un adult i de formació. 
Pregunta 5: Quines conseqüències, com a docent, preveus que pot produir l'ús del llenguatge de missatgeria instantània?

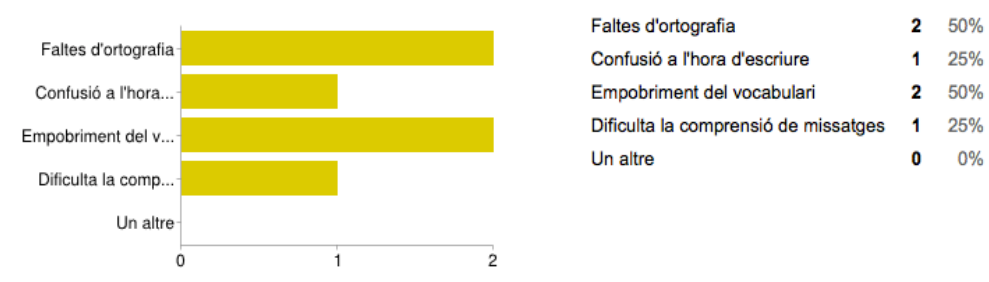

Figura 21. Resum de les respostes de la pregunta $n^{\circ} 5$ de l'enquesta als mestres. Font: Elaboració pròpia.

Pregunta 6: Observes algun rastre del llenguatge de missatgeria instantània en el teu alumnat durant el dia a dia? Sí és que sí, en quins contextos?

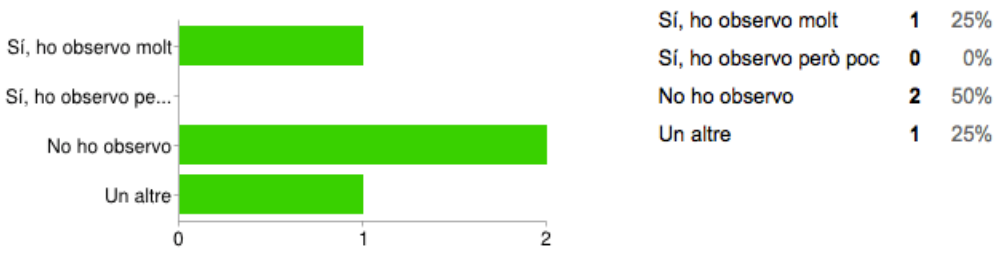

Figura 22. Resum de les respostes de la pregunta $n^{\circ} 6$ de l'enquesta als mestres. Font: Elaboració pròpia.

El 75\% dels docents enquestats coincideixen que no observen el llenguatge de missatgeria instantània en el seu dia a dia, així es pot evidenciar en l'anàlisi de textos o produccions de la mostra d'aquesta investigació on gairebé no hi ha cap rastre greu d'influència. Només un tutor o tutora ho observa, però no ha especificat el context. Es pot observar a la figura 22.

Pregunta 7: Què opines després de veure els resultats de les dades recollides?

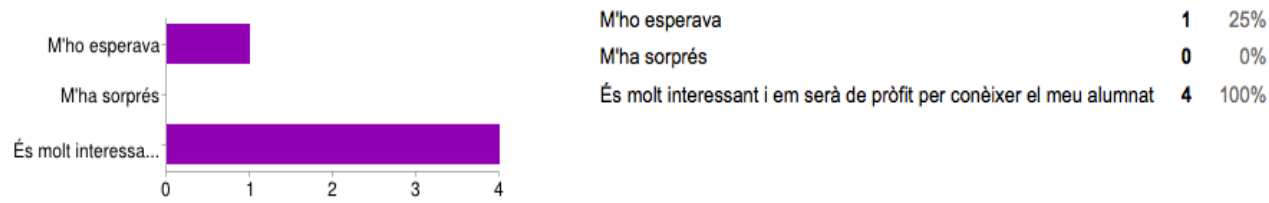

Figura 23. Resum de les respostes de la pregunta $n^{\circ} 7$ de l'enquesta als mestres. Font: Elaboració pròpia. 
Tots els docents responen que, un cop vistos els resultats, ho veuen molt interessat i d'utilitat per conèixer al seu alumnat. A més a més, hi ha un mestre/a que s'esperava aquests resultats. Es pot observar a la figura 23.

Pregunta 8: Canviaries alguna de les respostes de les preguntes anteriors després de veure els resultats?
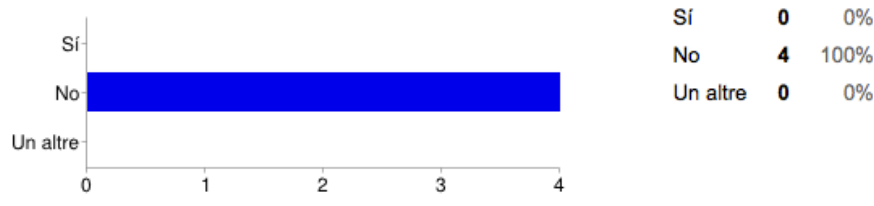

Figura 24. Resum de les respostes de la pregunta $n^{\circ} 8$ de l'enquesta als mestres. Font: Elaboració pròpia.

Pregunta 9: Creus que les variables: suport (ordinador, tauleta tàctil, escriptura a mà) i context (més formal o informal) influeix a l'hora d'utilitzar el llenguatge de missatgeria instantània per part de l'alumnat?



Figura 25. Resum de les respostes de la pregunta $n^{\circ} 9$ de l'enquesta als mestres. Font: Elaboració pròpia.

El $100 \%$ dels docents creuen que totes les variables influeixen en el moment d'utilitzar el llenguatge de missatgeria instantània (Figura 25). El mestre/a que respon també l'opció "un altre", especifica que quan escriuen a mà o amb ordinador en contextos formals, l'alumnat és conscient que no ha d'utilitzar aquest llenguatge, mentre que en les tauletes $i$ els teclats dels mòbils la influència és major perquè majoritàriament s'utilitzen en contextos informals i perquè no és tan còmode per escriure com en altres eines.

Pregunta 10: Quin creus que pot ser el resultat de la següent hipòtesi: L'alumnat de 6è de Primària presenta una influència en la seva escriptura del llenguatge de missatgeria instantània. Per què? 


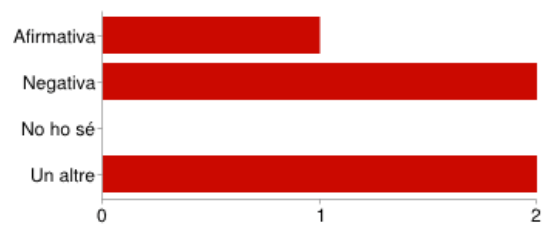

$\begin{array}{llr}\text { Afirmativa } & \mathbf{1} & 25 \% \\ \text { Negativa } & \mathbf{2} & 50 \% \\ \text { No ho sé } & \mathbf{0} & 0 \% \\ \text { Un altre } & \mathbf{2} & 50 \%\end{array}$

Figura 26. Resum de les respostes de la pregunta $\mathrm{n}^{\circ} 10$ de l'enquesta als mestres. Font: Elaboració pròpia.

En la figura 26 cal destacar que el $50 \%$ considera la hipòtesi negativa i un d'ells ho justifica dient que l'alumnat sap en quin context $i$ en quin no pot utilitzar el llenguatge de missatgeria instantània $i$ ho compara exposant el fet que els nens/es ho fan de la mateixa manera que ho fan els adults; I'altre no ho justifica. Un mestre/a sí que creu que la hipòtesi és afirmativa però no justifica la seva resposta. Finalment, el mestre/a que resta respon a l'apartat "un altre" valorant que comencen a estar influenciats però possiblement no tant com es pensa; justifica la seva resposta a partir de dos motius: primer creu que fa poc temps que el seu alumnat disposa de les eines tecnològiques $\mathrm{i}$, en segon Iloc, perquè encara no acaben de dominar suficientment el llenguatge de missatgeria instantània, aspecte condicionat pel temps que fa que disposen de les tecnologies.

\section{Conclusions}

Tal i com va anunciar Chomsky: "El llenguatge d'avui no és pitjor que el d'ahir. És més pràctic. Com el món en què vivim" (citat a Català i Jordà, 2015). Aquesta seria a una de les conclusions que es poden extreure després d'haver realitzat aquesta investigació. La societat evoluciona constantment en diferents àmbits i la comunicació n'és un exemple, especialment des de la recent evolució de la tecnologia. Les TIC han causat un impacte molt significatiu en la manera de transmetre informació i de comunicar-se i el llenguatge s'està modificant per adaptar-se als nous canvis del context social. Qui ho sap, però potser el que avui estem qualificant com a alteracions del llenguatge, d'aquí uns anys són estructures perfectament adaptades i utilitzades en la llengua habitual tal i com està passant amb els neologisme i altres mots de nova creació.

Després del procés d'investigació podem confirmar que la primera hipòtesi "L'alumnat de Gè de Primària presenta una influència en la seva escriptura del llenguatge de missatgeria instantània" es compleix. L'alumnat de 6è de Primària majoritàriament coneix el llenguatge de missatgeria instantània i sí que presenta una influencia en la seva escriptura en determinats contextos. Això es pot comprovar amb la varietat d'estructures i fórmules lingüístiques, típiques d'aquest llenguatge, utilitzades en l'activitat d'anàlisi de textos I també a partir de diferents preguntes de I'enquesta, que demostren l'alta disponibilitat tecnològica de l'alumnat, l'alta participació en xarxes socials i la comunicació per mitjà d'aquesta via. Finalment, 
també es veu a partir de la reflexió i cerca de la seva pròpia influencia en la seva escriptura.

Les següents hipòtesis estan estretament relacionades amb les variables presents en la investigació. Pel que fa la segona hipòtesi: "L'alumnat de 6è de Primària només utilitza el llenguatge de missatgeria instantània en contextos informals". Es pot demostrar afirmativament, tot observant les produccions escrites de l'alumnat, que els elements de llenguatge de missatgeria instantània són mínims i gairebé insignificants. La majoria de mestres afirmen que no veuen rastres en contextos formals com l'escola i, a més a més, aquests també creuen que la variable context és important perquè l'alumnat sap distingir quan usar aquest llenguatge i quan no, com es pot comprovar en les enquestes.

Finalment, analitzem la darrera hipòtesi: "L'alumnat de 6è de Primària presenta un ús major del llenguatge de missatgeria instantània quan utilitza suports electrònics per escriure que no pas quan escriu a mà". En les produccions manuscrites de l'alumnat la influència és mínima mentre que en l'escriptura en les tauletes tàctils i ordinador la influència és present i força considerable en la majoria dels participants, destacant que escriuen de la mateixa manera, ja sigui utilitzant les tauletes o l'ordinador com queda clar observant les produccions escrites de l'alumnat.

Es conclou la recerca afirmant que l'alumnat de 6è coneix el llenguatge de missatgeria instantània i l'utilitza en contextos de caire informal, per tant, la seva escriptura està influenciada, tot i així, no utilitzen aquest llenguatge a l'escola. Està clar que el fet de disposar de les tecnologies i de participar en xarxes socials en edats primerenques són les causants de la influencia. En l'actualitat, els mestres de Primària no tenen queixes importants, però no és així en els professors/es de secundària.

Les línies d'investigació futures haurien d'anar encaminades a comparar i analitzar per què, a l'etapa de Primària, l'alumnat és capaç de no utilitzar el llenguatge de missatgeria instantània en el context formal de l'escola i per què en cursos posteriors apareix una transferència. 


\section{Bibliografia}

Arnal, J., Latorre, A. i del Rincón, D. (1996). Bases metodológicas de la investigación educativa. Barcelona: Edicions Experiencia, S.L.

Bisquerra, R. (Coord.). (2009). Metodología de la investigación educativa. Madrid: La Muralla. S.A.

Bringué, X. i Sábada, C. (2009). Niños y adolescentes españoles ante las pantallas: rasgos configuradores de una generación interactiva. Disponible des d'Internet a: http://www.mecd.gob.es/revista-cee/pdf/n15-bringue-sala.pdf

Bringué, X. i Sábada, C. (2011). Menores y redes sociales. Foro generaciones interactivas 2011, Fundación Telefónica. Disponible des d'Internet a:

http://www.generacionesinteractivas.org/upload/libros/Libro-Menores-y-Redes-

Sociales_pd

Fernández, V., Fonseca, Ma G., Schmidt, M. i Vargas, A. (2011). El impacto del uso de la mensajería instantánea (IM) y la mensajería de texto vía celular (SMS) en la comunicación verbal de los estudiantes de primer ingreso en el 2011 de la Escuela de las Ciencias de la Comunicación Colectiva de la Universidad de Costa Rica. Disponible des d'Internet a:

http://cqinvestigo.wdfiles.com/local--files/cualitativas/El impacto del uso de la mensajería instantánea (IM) y la mensajería de texto vía celular

Català, X. i Jordà, V, (2015). Proverbia. [Bloc]. Disponible des d'Internet a: http://www.proverbia.net/citastema.asp?tematica $=350$

Cid Górriz, Robert. (2015). "La influència del llenguatge de missatgeria instantània en l'alumnat de 6è de primària". Treball Fi de Grau Educació Primària Universitat Rovira i Virgili CTE (Obtenció Matrícula d'Honor). Tutora: Dra. Núria Gil Duran.

Galan, C. (2002). En los arrabales de la comunicación: los mensajes sms. Anuario de estudios filológicos, vol. XXV, 103-117.

Instituto de la juventud. Ministerio de trabajo y asuntos sociales. (2006). Comunicación y lenguajes juveniles a través de las TIC. Fundación General de la Universidad Complutense de Madrid. Bernete, F. (Coord.). Disponible des d'Internet a: http://www.injuve.es/sites/default/files/comunicaciony20lenguajes20juveniles20TIC.p $\underline{\mathrm{df}}$

Instituto nacional de estadística (INE). (2013). Encuesta sobre Equipamiento y Uso de Tecnologías de Información y Comunicación en los Hogares (TIC-H). Notas de prensa. Disponible des d'Internet a: http://www.ine.es/prensa/np803.pdf

Levis, D. (2006). El chat: el habla escrita de niños y jóvenes. Disponible des d'Internet a: http://diegolevis.com.ar/secciones/Articulos/levis chat.pdf 
Ministerio de Educación, Cultura y Deportes. (2013) Educación conectada en tiempo de redes. [Imatge] Disponible des d'Internet a: http://blog.educalab.es/redes/tag/plan-de-comunicacion-externo/

Parrilla, E. A. (2008). Alteraciones del lenguaje en la era digital. XV (30), 131 - 136. España: Grupo Comunicar. Revista Científica de Comunicación y Educación; ISSN: 1134-3478; páginas 131-136. Disponible des d'Internet a:

https://prezi.com/517ap-idicuj/alteraciones-del-lenguaje-en-la-era-digital 